\title{
Analisis Sistem Persediaan Bahan Baku Air Kelapa pada Industri Nata de Coco (Studi Kasus PT Keong Nusantara Abadi)
}

\section{(Analysis of Coconut Water Raw Material Inventory Systems in the Nata de Coco Industry [Case Study in the PT Keong Nusantara Abadi])}

\author{
Shella Puji Pangesti ${ }^{1)^{*}}$, Fadila Marga Saty ${ }^{2)}$, Dewi Riniarti ${ }^{2)}$ \\ 1) Program Studi Produksi dan Manajemen Industri Perkebunan, Jurusan Budidaya Tanaman \\ Perkebunan, Politeknik Negeri Lampung, Jl. Soekarno-Hatta No. 10 Rajabasa, Bandar Lampung, \\ 35144, Telp.:(0721) 703995, Fax.: (0721)787309 dan 2) Jurusan Budidaya Tanaman Perkebunan, \\ Politeknik Negeri Lampung, Jl. Soekarno-Hatta No. 10 Rajabasa, Bandar Lampung, 35144, \\ Telp.:(0721) 703995, Fax.: (0721)787309 \\ Email: Shellapujipangesti97@gmail.com
}

\begin{abstract}
Inventory is an important thing for the industrial company, so determination of order quantity must be done optimally and reduce the inventory cost. PT Keong Nusantara Abadi is an industrial company for processing of nata de coco that requires an inventory control system so that the purchase of raw material becomes optimal. Therefore, this research was conducted to analyze inventory control carried out by PT Keong Nusantara Abadi and determine alternative methods of inventory control of raw material for the company. This research use Material Requirement Planning (MRP) system. MRP system has two ways to determine the order quantity called lot sizing decision. Techniques for determining the quantity of order is Economic Order Quantity (EOQ), Lot for Lot (LFL), and Part Periode Balancing (PPB). The technique of determining the order quantity that is best use by PT Keong Nusantara Abadi is EOQ which result in lower inventory cost than inventory control techniques by the company that is saved by 9\%, 10\%, 7,3\% consecutively during 2015, 2016, and 2017.
\end{abstract}

Keyword: EOQ, inventory control, $L F L, P P B$

DOI: http://dx.doi.org/ 10.25181/jaip.v7i2.1111

Diterima: 23 April 2019 / Disetujui: 29 September 2019 / Diterbitkan: 16 Oktober 2019

\section{PENDAHULUAN}

Kelapa merupakan tanaman tropis yang penting bagi negara-negara di Asia dan Pasifik. Kelapa selain dapat memberikan devisa bagi negara juga merupakan mata pencarian jutaan petani yang mampu memberikan penghidupan puluhan juta keluarganya. Indonesia merupakan negara produsen kelapa terbesar di dunia. Pada 2016, produksi kelapa Indonesia mencapai 18,3 juta ton dan merupakan yang tertinggi didunia. Luas areal kelapa di Indonesia mencapai 3,74 juta ha. Luas areal kelapa untuk perkebunan rakyat mencapai 99\% (Direktorat Jenderal Perkebunan, 2015). 
Jumlah produksi kelapa yang tinggi dimanfaatkan oleh industri pengolahan air kelapa sebagai bahan baku pembuatan nata de coco.

Setiap perusahaan khususnya perusahaan industri membutuhan persediaan bahan baku agar proses produksi tidak terganggu dan dapat menimbulkan kerugian bagi perusahaan. Veronica (2013) menjelaskan bahwa persediaan merupakan suatu aktiva yang meliputi barang-barang milik perusahaan yang akan dijual dalam suatu periode tertentu, atau persediaan barang-barang yang masih dalam pengerjaan/proses produksi, ataupun persediaan bahan baku yang masih menunggu penggunaannya dalam suatu proses produksi. Persediaan yang ditetapkan oleh perusahaan tidak terlalu sedikit ataupun terlalu banyak. Persediaan yang terlalu sedikit akan menghambat jalannya proses produksi, sedangkan persediaan yang terlalu banyak akan meningkatkan biaya persediaan.

PT Keong Nusantara Abadi merupakan perusahaan manufaktur yang bergerak dalam bidang pengolahan nata de coco dan makanan kaleng berupa keong. Persediaan air kelapa dipasok dari supplier tetap yang telah bekerjasama dengan PT Keong Nusantara Abadi. PT Keong Nusantara Abadi membeli air kelapa sesuai dengan kebutuhan yang direncanakan oleh bagian Planning Production and Inventory Control (PPIC) dan ditambah dengan air kelapa yang akan dijadikan persediaan untuk hari berikutnya.

PT Keong Nusantara Abadi membutuhkan suatu sistem yang dapat digunakan untuk menentukan jumlah pembelian bahan baku sehingga pembelian dilakukan dengan optimal dan biaya persediaan bahan baku dapat ditekan. Heizer dan Render, 2005 (dalam Utami, 2012) menjelaskan bahwa MRP (Material Requirement Planning) merupakan suatu teknik permintaan terikat yang menggunakan daftar kebutuhan bahan, persediaan, penerimaan yang diperkirakan, dan jadwal produksi induk untuk menentukan kebutuhan material. Penerapan metode MRP dapat menentukan berapa banyak bahan baku yang diperlukan untuk memenuhi jadwal produksi induk. Penentuan lot size (ukuran kuantitas pemesanan) dalam metode MRP disebut dengan lot sizing decision (keputusan menentukan ukuran pemesanan). Tujuan dilakukannya penelitian adalah untuk menentukan metode alternatif pengendalian persediaan bahan baku di PT Keong Nusantara Abadi yang diperoleh dari hasil analisis perbandingan antara pengendalian persediaan bahan baku yang dilakukan oleh perusahaan dengan hasil analisis pengendalian persediaan bahan baku dengan sistem MRP. Penentuan ukuran pemesanan dapat dilakukan dengan banyak metode. Metodemetode tersebut dikelompokkan berdasarkan karakteristik sifat lot size yang dinamis atau statis.

\section{METODE PENELITIAN}

Penelitian ini merupakan penelitian deskriptif dengan pendekatan komparatif yang dipergunakan untuk membahas mengenai perbandingan penentuan persediaan bahan baku yang diterapkan perusahaan dan penentuan persediaan bahan baku dengan metode EOQ, LFL, dan PPB. Assauri (2008) menjelaskan bahwa jumlah atau besarnya pesanan yang diadakan hendaknya 
menghasilkan biaya-biaya yang timbul dalam penyediaan adalah minimal sehingga dapat menentukan waktu dan jumlah yang tepat untuk melakukan pemesanan, sedangkan metode LFL merupakan teknik penentuan ukuran kuantitas pemesanan yang paling sederhana. Purwanti dalam Dwika (2010) menyatakan bahwa teknik LFL menyediakan persediaan berdasarkan jumlah yang diperlukan saja, sehingga biaya penyimpanan menjadi nol. Metode PPB adalah teknik melakukan pemesanan sebesar kebutuhan pada suatu periode yang dapat digabungkan. Penggabungan periode dilakukan untuk gabungan periode berurutan yang memiliki nilai kumulatif bagian periode mendekati nilai Economic Part Periode (EPP).

Data yang digunakan dalam penelitian ini adalah data sekunder yang didapatkan dari PT Keong Nusantara Abadi yakni data tahun 2015, 2016, dan 2017 berupa data pembelian bahan baku, kebutuhan bersih air kelapa, persediaan air kelapa, biaya untuk melakukan pemesanan bahan baku, biaya pemeliharaan bahan baku yang telah dibeli perusahaan, proses produksi nata de coco, dan data pendukung berupa literatur dan penelitian terdahulu yang berkaitan dengan penelitian ini. Penelitian dilaksanakan selama satu bulan yakni mulai bulan Juli 2018 sampai Agustus 2018. Metode analisis yang dilakukan yaitu menganalisis pengendalian persediaan bahan baku yang dilakukan PT Keong Nusantara Abadi, metode MRP teknik EOQ, metode MRP teknik LFL, metode MRP teknik PPB, menganalisis perbandingan antara metode MRP teknik EOQ, LFL, dan PPB dengan kebijakan pengendalian persediaan yang dilakukan perusahaan, menentukan persediaan pengaman (safety stock), dan menentukan titik pemesanan kembali (reorder point).

\section{HASIL DAN PEMBAHASAN}

\section{Analisis Pengendalian Persediaan Bahan Baku PT Keong Nusantara Abadi}

Sistem pengendalian bahan baku yang diterapkan oleh PT Keong Nusantara Abadi belum terstruktur dengan baik. Pengadaan bahan baku dilakukan sesuai dengan rencana produksi yang ditetapkan oleh bagian Planning Production and Inventory Control (PPIC) ditambah dengan bahan baku yang akan dijadikan persediaan untuk hari selanjutnya. Penambahan persediaan bahan baku untuk hari selanjutnya dilakukan dengan melihat kondisi persediaan yang disimpan. Pembelian air kelapa oleh PT Keong Nusantara Abadi mulai tahun 2015 hingga tahun 2017 mengalami peningkatan. Hal ini dikarenakan jumlah pemakaian yang semakin meningkat, sehingga berpengaruh pada banyaknya pembelian serta meningkatnya frekuensi pemesanan yang dilakukan oleh perusahaan (Tabel 1). 
Tabel 1. Pembelian air kelapa oleh PT Keong Nusantara Abadi

\begin{tabular}{lcccc}
\hline \multicolumn{1}{c}{ Bulan } & 2015 (liter) & 2016 (liter) & 2017 (liter) & Rata-rata (liter) \\
\hline Januari & 438.500 & 545.100 & 633.500 & 539.033 \\
Februari & 438.800 & 552.400 & 637.000 & 542.733 \\
Maret & 438.500 & 547.700 & 633.000 & 539.733 \\
April & 437.100 & 551.300 & 635.500 & 541.300 \\
Mei & 438.800 & 549.100 & 653.500 & 547.133 \\
Juni & 436.900 & 548.800 & 638.000 & 541.233 \\
Juli & 437.100 & 547.300 & 638.500 & 540.967 \\
Agustus & 537.000 & 544.800 & 642.000 & 574.600 \\
September & 536.000 & 543.500 & 644.000 & 574.500 \\
Oktober & 535.800 & 544.500 & 642.500 & 574.267 \\
November & 536.600 & 547.300 & 643.500 & 575.800 \\
Desember & 536.500 & 545.100 & 646.000 & 575.867 \\
\hline Total & 5.747 .600 & 6.566 .900 & 7.669 .000 & 6.667 .166 \\
\hline Rata-rata & 478.967 & 547.242 & 639.083 & \\
\hline
\end{tabular}

Sumber: PT Keong Nusantara Abadi (laporan tahunan), 2017

Tabel 1 menyajikan jumlah pembelian air kelapa pada tahun 2015, 2016, dan 2017 yang mengalami peningkatan. Peningkatan pembelian air kelapa dipengaruhi oleh jumlah pemakaian air kelapa serta frekuensi pemesanan yang dilakukan perusahaan. Jumlah pemakaian air kelapa meningkat dikarenakan terjadi pemaksimalan kapasitas produksi yaitu sebanyak 30.000 liter air kelapa per hari.

Biaya persediaan yang dikeluarkan oleh perusahaan merupakan jumlah dari biaya pemesanan, biaya penyimpanan, dan biaya pembelian air kelapa. Berikut adalah Tabel 2 menyajikan rincian total biaya persediaan yang dikeluarkan oleh PT Keong Nusantara Abadi pada tahun 2015, 2016, dan 2017:

Tabel 2. Rincian total biaya persediaan oleh PT Keong Nusantara Abadi

\begin{tabular}{|c|c|c|c|}
\hline \multirow{2}{*}{ Jenis biaya } & \multicolumn{3}{|c|}{ Jumlah (Rp) } \\
\hline & 2015 & 2016 & 2017 \\
\hline Biaya pemesanan & 10.140 .000 & 14.352 .000 & 15.600 .000 \\
\hline Biaya pembelian & 2.299 .040 .000 & 2.955 .105 .000 & 3.451 .050 .000 \\
\hline Biaya penyimpanan & 63.234 .000 & 67.320 .000 & 78.073 .272 \\
\hline Total biaya persediaan & 2.372 .414 .000 & 3.036 .777 .000 & 3.544 .723 .272 \\
\hline
\end{tabular}

Sumber: Data sekunder (diolah), 2018

Pada Tabel 2 diketahui bahwa biaya persediaan yang dikeluarkan oleh PT Keong Nusantara Abadi dari tahun 2015 sampai 2017 mengalami peningkatan sebesar 33\%. Peningkatan ini dipengaruhi oleh biaya pemesanan, biaya pembelian, serta biaya penyimpanan yang juga mengalami peningkatan setiap tahunnya. 


\section{Analisis Pengendalian Persediaan Bahan Baku Metode MRP Teknik EOQ}

Berdasarkan hasil rincian total biaya persediaan oleh PT Keong Nusantara Abadi dan hasil analisis teknik EOQ Tahun 2015, 2016, dan 2017 didapatkan penghematan biaya persediaan seperti pada Tabel 3 .

Tabel 3. Penghematan biaya persediaan dengan teknik EOQ

\begin{tabular}{lrrrrrr}
\hline \multirow{1}{*}{\multicolumn{1}{c}{ Jenis biaya }} & \multicolumn{5}{c}{ Jumlah $(\mathrm{Rp})$} \\
\cline { 2 - 7 } & \multicolumn{1}{c}{2015} & \multicolumn{2}{c}{2016} & \multicolumn{1}{c}{2017} \\
\cline { 2 - 7 } & \multicolumn{1}{c}{$(\mathrm{Rp})$} & \multicolumn{1}{c}{$(\%)^{*}$} & $(\mathrm{Rp})$ & $(\%)^{*}$ & $(\%)^{*}$ \\
\hline Biaya pemesanan & 8.762 .000 & 13,6 & 10.681 .200 & 25,6 & 14.280 .000 & 8,5 \\
Biaya pembelian & 2.124 .786 .217 & 7,6 & 2.696 .279 .485 & 8,8 & 3.252 .839 .932 & 5,7 \\
Biaya penyimpanan & 21.620 .885 & 65,8 & 20.953 .158 & 68,9 & 20.473 .514 & 73,8 \\
\hline Biaya persediaan & 2.155 .169 .102 & 9 & 2.727 .913 .843 & 10 & 3.287 .656 .446 & 7,3 \\
\hline
\end{tabular}

Sumber: Data sekunder (diolah), 2018

*Rumus penghematan biaya:

$\frac{\text { biaya persediaan perusahaan-biaya persediaan } E O Q}{\text { biaya persediaan perusahaan }} \times 100 \%$

Tabel 3 menunjukkan bahwa terjadi penghematan biaya persediaan bahan baku dari tahun 2015 sampai tahun 2017 yakni sebesar 8,8\%, dengan demikian terjadi penghematan biaya persediaan sebesar Rp783.174.881 sehingga menghasilkan biaya persediaan yang lebih rendah dari biaya yang harus dikeluarkan oleh perusahaan. Penelitian milik Anny (2016) menyimpulkan bahwa sistem persediaan yang dilakukan oleh PT Dimembe Nyiur Agripro belum efisien karena biaya biaya persediaannya lebih besar jika dibandingkan dengan metode EOQ. Besarnya tingkat kebutuhan bahan baku per periode dengan persentase biaya simpan untuk bahan baku berpengaruh pada biaya-biaya persediaan (Aryantha, 2015).

\section{Analisis Pengendalian Persediaan Bahan Baku Metode MRP Teknik LFL}

Berdasarkan hasil rincian total biaya persediaan oleh PT Keong Nusantara Abadi dan hasil analisis teknik LFL Tahun 2015, 2016, dan 2017 dihasilkan penghematan biaya persediaan seperti pada Tabel 4.

Tabel 4. Penghematan biaya persediaan dengan teknik LFL

\begin{tabular}{lrrrrrr}
\hline \multirow{2}{*}{\multicolumn{1}{c}{ Jenis biaya }} & \multicolumn{6}{c}{ Jumlah $(\mathrm{Rp})$} \\
\cline { 2 - 7 } & \multicolumn{1}{c}{$(\mathrm{Rp})$} & $(\%)$ & \multicolumn{1}{c}{2016} & \multicolumn{1}{c}{2017} \\
\cline { 2 - 7 } & 9.282 .000 & 8,5 & 13.137 .600 & 8,5 & 14.280 .000 & 8,5 \\
\hline Biaya pemesanan & 2.111 .200 .000 & 8,2 & 2.687 .175 .000 & 9,1 & 3.225 .600 .000 & 6,5 \\
Biaya pembelian & 185.709 & 99,7 & 285.185 & 99,6 & 128.199 & 99,8 \\
Biaya penyimpanan & 2.120 .667 .709 & 11 & 2.700 .597 .785 & 11 & 3.239 .880 .000 & 8,6 \\
\hline Biaya persediaan & & & & &
\end{tabular}


*Rumus penghematan biaya:

$\frac{\text { biaya persediaan perusahaan-biaya persediaan } L F L}{\text { biaya persediaan perusahaan }} \times 100 \%$

Berdasarkan Tabel 4 diketahui bahwa penerapan teknik LFL di PT Keong Nusantara Abadi selama tiga tahun yakni tahun 2015, 2016, dan 2017 akan menghasilkan penghematan biaya persediaan sebanyak 10,2\%, dengan demikian akan dihemat biaya persediaan sebesar Rp892.768.774.

\section{Analisis Pengendalian Persediaan Bahan Baku Metode MRP Teknik PPB}

Berdasarkan hasil rincian total biaya persediaan oleh PT Keong Nusantara Abadi dan hasil analisis teknik PPB Tahun 2015, 2016, dan 2017 dihasilkan penghematan biaya persediaan seperti pada Tabel 5.

Tabel 5. Penghematan biaya persediaan dengan teknik PPB

\begin{tabular}{lrrrrrr}
\hline & \multicolumn{7}{c}{ Jumlah (Rp) } \\
\cline { 2 - 7 } \multicolumn{1}{c}{ Jenis biaya } & \multicolumn{1}{c}{2015} & \multicolumn{1}{c}{2016} & \multicolumn{1}{c}{2017} \\
\cline { 2 - 7 } & \multicolumn{1}{c}{$(\mathrm{Rp})$} & $(\%)$ & $(\mathrm{Rp})$ & \multicolumn{1}{c}{$(\%)$} & \multicolumn{1}{c}{$(\mathrm{Rp})$} & $(\%)$ \\
\hline Biaya pemesanan & 9.360 .000 & 7,7 & 10.212 .000 & 28,8 & 13.200 .000 & 15,4 \\
Biaya pembelian & 2.118 .000 .000 & 7,7 & 2.747 .250 .000 & 7,0 & 3.240 .000 .000 & 6,1 \\
Biaya penyimpanan & 33.454 .812 & 47,1 & 76.991 .615 & \multicolumn{1}{c}{-} & 50.528 .518 & 35,3 \\
\hline Biaya persediaan & 2.160 .814 .812 & 8,9 & 2.834 .453 .615 & 6,7 & 3.303 .728 .518 & 6,8 \\
\hline
\end{tabular}

Sumber: Data sekunder (diolah), 2018

*Rumus penghematan biaya:

$\frac{\text { biaya persediaan perusahaan-biaya persediaan } P P B}{\text { biaya persediaan perusahaan }} \times 100 \%$

Tabel 5 menyatakan bahwa terjadi penghematan biaya rata-rata selama tahun 2015, 2016, dan 2017 adalah sebesar 7,5\%, sehingga akan dihemat biaya persediaan sebesar Rp654.917.327 meskipun pada tahun 2016 tidak ada penghematan biaya penyimpanan bahan baku dikarenakan adanya penambahan kebutuhan pembelian sampai nilai bagian periode mencapai EPP sehingga persediaan yang disimpan lebih banyak, namun total biaya persediaan lebih rendah dibandingkan dengan total biaya persediaan yang dilakukan oleh perusahaan.

\section{Analisis Perbandingan Metode MRP Teknik EOQ, LFL, dan PPB dengan Kebijakan Pengendalian Persediaan Perusahaan}

Penerapan metode MRP teknik LFL, EOQ, dan PPB menghasilkan total biaya persediaan yang lebih rendah bila dibandingkan dengan metode yang diterapkan oleh perusahaan. Teknik LFL menghasilkan total biaya terendah bila dibandingkan dengan teknik EOQ dan PPB. Berikut ini adalah Tabel 6 menyajikan perbandingan biaya persediaan teknik LFL, EOQ, dan PPB. 
Tabel 6. Perbandingan penghematan biaya persediaan teknik LFL, EOQ, PPB dan kebijakan perusahaan

\begin{tabular}{|c|c|c|c|c|c|c|}
\hline \multirow{2}{*}{ Metode } & 2015 & 2016 & 2017 & 2015 & 2016 & 2017 \\
\hline & \multicolumn{3}{|c|}{ Biaya persediaan (Rp) } & \multicolumn{3}{|c|}{ Penghematan $(\%)^{*}$} \\
\hline Perusahaan & 2.372 .414 .000 & 3.036 .777 .000 & 3.544 .723 .272 & & & \\
\hline EOQ & 2.155 .169 .102 & 2.727.913.843 & 3.287 .656 .446 & 9 & 10 & 7,3 \\
\hline LFL & 2.120 .667 .709 & 2.700 .597 .785 & 3.239 .880 .000 & 11 & 11 & 8,6 \\
\hline PPB & 2.160 .814 .812 & 2.834 .453 .615 & 3.303 .728 .518 & 8,9 & 6,7 & 6,8 \\
\hline
\end{tabular}

Sumber: Data sekunder (diolah), 2018

*Rumus penghematan biaya:

$\frac{\text { biaya persediaan perusahaan-biaya persediaan hasil analisis }}{\text { biaya persediaan perusahaan }} \times 100 \%$

Pada Tabel 6 penghematan biaya persediaan tertinggi adalah pada teknik LFL, selanjutnya adalah teknik EOQ dan PPB. Rendahnya total biaya persediaan dengan teknik LFL dikarenakan biaya penyimpanan yang dihasilkan rendah. Berbeda dengan teknik EOQ, teknik PPB, maupun metode yang telah diterapkan perusahaan, biaya penyimpanan lebih tinggi karena adanya bahan baku yang disimpan. Pada penerapan teknik LFL, persediaan yang disediakan sesuai dengan kebutuhan produksi yang diperlukan sehingga biaya penyimpanan bahan baku menjadi nol karena tidak ada persediaan yang disimpan.

Teknik LFL yang tidak menghendaki adanya bahan baku yang disimpan belum dapat diterapkan oleh PT Keong Nusantara Abadi karena dalam perusahaan tersebut persediaan bahan baku dibutuhkan agar tidak terjadi kekurangan bahan baku bila sewaktu-waktu ada supplier yang tidak dapat memenuhi jumlah bahan baku yang dipesan oleh perusahaan. Teknik EOQ menjadi metode alternatif yang tepat untuk diterapkan oleh PT Keong Nusantara Abadi karena menghasilkan biaya persediaan yang lebih rendah dari metode perusahaan serta tersedianya bahan baku yang disimpan. Teknik EOQ juga memberikan asumsi-asumsi yang harus terpenuhi supaya teknik EOQ dapat diterapkan antara lain permintaan konstan dan seragam, harga per satuan seragam, biaya pemesanan konstan, pengiriman seketika, dan pesanan independent (Herlambang \& Dewi, 2017). Asumsi-asumsi tersebut dilakukan untuk mempermudah dalam perhitungan penjadwalan pemesanan bahan baku dengan teknik EOQ. Penelitian milik Fachrurrozi (2015) meyimpulkan bahwa dari metode MRP yang telah dilakukan yaitu LFL, FOQ, EOQ, dan POQ diperoleh biaya pengadaan material paling rendah. Namun, teknik LFL kurang optimal karena tidak adanya persediaan pengaman, sehingga dipilih metode yang paling optimal dan ekonomis yaitu metode FOQ dikarenakan total biaya persediaan terendah kedua setelah LFL dan memiliki persediaan pengaman yang tidak terlalu besar. Keunggulan teknik EOQ yakni mempermudah penentuan jumlah pemesanan yang optimal dalam setiap kali pemesanan. Teknik EOQ juga memenuhi kebijakan perusahaan dalam tersedianya bahan baku dalam jumlah yang cukup (Muzayyanah, 2015). 
Hasil dari penelitian sejenis menunjukkan bahwa dengan penggunaan metode MRP dalam teknik menentukan ukuran kuantitas pemesanan dihasilkan pengefisiensian biaya dalam pengadaan bahan baku. Penelitian milik Efendi (2015) menyimpulkan bahwa penggunaan metode MRP teknik EOQ menghasilkan efisiensi biaya pemesanan yang dilakukan PG (Pabrik Gula) Ngadiredjo dengan selisih 1.128,8 ton per hari giling atau terjadi pemborosan sebesar Rp5.003.945,10 per hari giling.

\section{Persediaan Pengaman (Safety Stock)}

Persediaan pengaman merupakan persediaan cadangan yang disiapkan oleh perusahaan apabila terjadi keterlambatan datangnya bahan baku. Persediaan pengaman berfungsi sebangai pelindung dari ketidakpastiaan permintaan maupun pasokan PT Keong Nusantara Abadi. Waktu tunggu sampai bahan baku datang adalah dua hari dan rata-rata penggunaan bahan baku pada tahun 2015 adalah 441.667 liter sehingga diperlukan persediaan pengaman sebesar 16.273 liter per hari. Pada tahun 2016 persediaan pengaman yang harus disiapkan oleh perusahaan adalah sebanyak 21.447 liter per hari dengan rata-rata pemakaian bahan baku 500.000 liter. Tahun 2017 diperlukan persediaan pengaman sebanyak 32.857 liter per hari dengan rata-rata pemakaian bahan baku sebanyak 600.000 liter.

\section{Titik Pemesanan Kembali (Reorder Point)}

Titik pemesanan kembali merupakan titik dimana perusahaan untuk mengadakan pemesanan kembali pada saat yang tepat sehingga perusahaan tidak mengalami kehabisan persediaan. PT Keong Nusantara Abadi, pada tahun 2015 dapat melakukan pemesanan kembali air kelapa jika persediaan air kelapa yang disimpan telah mencapai 16.273 liter per hari, tahun 2016 dan 2017 pemesanan kembali air kelapa dapat dilakukan jika air kelapa yang disimpan telah mencapai 21.447 dan 32.857 liter per hari.

\section{KESIMPULAN DAN SARAN}

\section{Kesimpulan}

Berdasarkan hasil penelitian maka dapat disimpulkan bahwa sistem pengendalian persediaan bahan baku air kelapa yang dilakukan oleh PT Keong Nusantara Abadi belum terstruktur dengan baik, sehingga metode alternatif dalam penentuan ukuran lot yang paling efisien dapat digunakan oleh perusahaan adalah metode MRP teknik Econommic Order Quantity (EOQ) yang menghasilkan biaya persediaan lebih rendah dibandingkan metode yang dilakukan oleh perusahaan. 


\section{Saran}

Metode MRP teknik Econommic Order Quantity (EOQ) direkomendasikan untuk dapat diterapkan oleh PT Keong Nusantara Abadi. Penerapan teknik EOQ ini dapat menghemat biaya pengadaan bahan baku yang akan dilakukan oleh perusahaan. Data yang digunakan adalah data tahun 2015, 2016, dan 2017 sehingga untuk tahun-tahun selanjutnya perusahaan dapat memperbaharui data yang ada.

\section{DAFTAR PUSTAKA}

Aryantha, M. I. \& Anggraeni, N. (2015). Analisis Perencanaan Pengendalian Bahan Baku Menggunakan Teknik Lotting di PT Agronesia Inkaba Bandung. Jurnal Teknik Industri.

Assauri (2008). Manajemen Produksi dan Operasi. Lembaga Penerbit Fakultas Ekonomi Universitas Indonesia. Jakarta.

Direktorat Jenderal Perkebunan. (2015). Statistik Perkebunan Kelapa Indonesia 2013-2015. Jakarta.

Dwika, E. I. (2010). Penerapan Material Requirements Planning (MRP) dalam Perencanaan Persediaan Bahan Baku Jamu Sehat Perkasa pada PT Nyonya Meneer. Unpublished undergraduate thesis, Universitas Diponegoro, Semarang.

Efendi, V. (2015). Analisis Penyediaan Bahan Baku Tebu di Pabrik Gula Ngadiredjo PT. Perkebunan Nusantara $X$ (Persero). Unpublished undergraduate thesis, Universitas Jember, Jember.

Fachrurrozi, F., \& Almahdy, I. (2016). Lot sizing material requirement planning pada produk tipe wall mounting di industri box panel. Penelitian dan Aplikasi Sistem dan Teknik Industri, 10(3), 279-293.

Herlambang, A. I. P., \& Dewi, R. (2018). Pengendalian persediaan bahan baku beras dengan metode economic order quantity (EOQ) multi produk guna meminimumkan biaya (Studi kasus pada CV. Lumbung Tani Sejahterah). Jurnal Ekonomi dan Bisnis, 2(02), 525-542.

Loho, A. E., \& Lolowang, T. F. (2016). Analisis persediaan bahan baku kelapa pada PT. Dimembe Nyiur Agripro (DNA) di Desa Tetey, Kecamatan Dimembe, Kabupaten Minahasa Utara. AgriSosioekonomi, 12(2A), 251-260.

Muzayyanah, Suamba, I. K., \& Dewi, R. K. (2015). Analisis pengendalian persediaan bahan baku biji kakao pada Pabrik Delicacao Bali di Kabupaten Tabanan. Jurnal Agribisnis dan Agrowisata, 4(4), 268-277.

Utami, W. T. (2012). Analisis Pengendalian Persediaan Bahan Baku Pada PT. XYZ, Jakarta (Studi Kasus pada Painting Plastic Part Honda OEM). Unpublished undergraduate thesis, Institut Pertanian Bogor, Bogor.

Veronica, M. A. (2013). Analisis Pengendalian Persediaan Bahan Baku Beras dengan Metode Economic Order Quality (EOQ) Multi Produk Guna Meminimumkan Biaya pada CV. Lumbung Tani Makmur di Banyuwangi. Unpublished undergraduate thesis, Universitas Jember, Jember. 